\title{
New Hydrangeas for North and Central Florida: Bigleaf and Mountain Hydrangeas ${ }^{1}$
}

Gary W. Knox ${ }^{2}$

A "hydrangea" to most people is a shade-preferring shrub producing ball-shaped or flat clusters of white, pink, blue or purple flowers, depending on soil conditions and cultivar. Hydrangeas with ball-shaped flower clusters are often called "mophead" or "hortensia"

hydrangeas whereas "lacecap" hydrangeas have flat clusters of tiny, spidery flowers surrounded by a ring of prominent flowers. Bigleaf hydrangea (Hydrangea macrophylla $)^{3}$ and mountain hydrangea (H. serrata) are the two species most commonly associated with these descriptions of "hydrangea."

Many new cultivars of hydrangea have been introduced in recent years. Gardeners and landscapers have renewed interest in hydrangea because it flowers in shade, often produces blue flowers, and is considered an "heirloom" plant that reminds us of the garden heritage of our forefathers. Some of the new cultivars reflower throughout the summer, providing more garden impact and strengthening the ongoing appreciation of hydrangea. This revitalized enthusiasm for hydrangea is bringing greater attention to the historic varieties of hydrangea as well as inviting efforts to improve hydrangea through new selection and breeding programs.

\section{Reflowering Hydrangeas}

The discovery and development of reflowering hydrangeas revolutionized the market and demand for these shrubs. Reflowering hydrangeas produce an initial flush of flowers followed by sporadic flowering or later flushes of flowers in the same growing season. Though some older cultivars are considered "free-flowering," it is the newer, "everblooming" or "remontant" cultivars that have been lauded and subsequently promoted with elaborate marketing campaigns.

Reflowering may occur on old wood (stems developed the previous year) or on new wood (new growth developed during the current growing season). All hydrangeas flower from buds formed in the tips of stems the previous year (on old wood). Some hydrangeas also form flower buds the previous year in buds up and down the stems (not just at the tips). These flower buds may develop and flower weeks or months after the terminal flower buds bloom in early summer. Hydrangeas with this pattern of reflowering are called "free-flowering." Free-flowering hydrangeas have been recognized by collectors and breeders for decades, but they were never commercially promoted on a large scale.

1. This document is ENH1034, one of a series of the Environmental Horticulture Department, Florida Cooperative Extension Service, Institute of Food and Agricultural Sciences, University of Florida. Original publication date March 16, 2006. Visit the EDIS Web Site at http://edis.ifas.ufl.edu.

2. Extension Specialist and Professor of Environmental Horticulture, University of Florida/IFAS, North Florida Research and Education Center, 155 Research Road, Quincy, FL 32351.

The Institute of Food and Agricultural Sciences (IFAS) is an Equal Opportunity Institution authorized to provide research, educational information and other services only to individuals and institutions that function with non-discrimination with respect to race, creed, color, religion, age, disability, sex, sexual orientation, marital status, national origin, political opinions or affiliations. U.S. Department of Agriculture, Cooperative Extension Service, University of Florida, IFAS, Florida A. \& M. University Cooperative Extension Program, and Boards of County Commissioners Cooperating. Larry Arrington, Dean 
"Everblooming" hydrangeas reflower on new wood. In this case, flower buds form in the tips of new growth, and these buds will continue to develop and ultimately flower later in the same year. Technically called "remontant," hydrangeas with this characteristic have the ability to flower almost continuously throughout the growing season.

The first commercially promoted remontant or everblooming hydrangea was noted by renowned plantsman, Dr. Michael Dirr. He first saw this hydrangea in the trial garden of a wholesale nursery in Minnesota. One of the nursery employees had noticed that a neighbor's hydrangea flowered late in the year, and he was given permission to propagate and test the plant. Years later, Dr. Dirr visited the nursery, saw this hydrangea flowering in September and realized this plant had great garden and commercial value. This plant was given the cultivar name of 'Bailmer' and is now widely known as Endless Summer ${ }^{\circledR}$ hydrangea. This plant has been promoted with an elaborate marketing campaign, resulting in nation-wide awareness and huge sales.

Shortly after this discovery, Dr. Dirr and others realized similar reflowering hydrangeas occurred in a few home gardens across the U.S. Their owners had often recognized the reflowering ability of the plant, and may have shared the plant with friends and neighbors, but no one had tried to commercialize the plant. These scattered plants were unique and subsequently collected under the names of 'David Ramsey', 'Decatur Blue', 'Oak Hill' and 'Penny Mac'. In addition, a number of old cultivars of hydrangea were noted in the literature as having reflowering characteristics, but were never widely promoted.

Table 1 lists new cultivars that are remontant (reflower on new growth) and generally available. Other everblooming cultivars that may be found at specialty nurseries are $H$. macrophylla 'All Summer Beauty' and H. serrata cultivars 'Blue Deckle' and 'Coerulea Lace'.

Table 2 lists cultivars that are free-flowering (late flushes of flowers originate on old wood) and somewhat available. Other free-flowering cultivars that may be purchased from specialty nurseries are $H$. macrophylla 'Altona', 'Bodensee', 'Bouquet Rose',
'Forever Pink', 'Frillibet', 'Gold Nugget', 'Goliath', 'Heinrich Seidel', 'La France', 'Mme Faustin Travouillon', 'Marechal Foch', 'Mousseline', 'Niedersachsen', 'Otaksa', 'Patio White', 'President R. Touchard', 'Princess Beatrix', 'Todi', 'Trophy', 'Wayne's White' and 'Wildenstein'. 'Ayesha' and 'Tovelit' also are reported to reflower in north Florida.

\section{Other New or Notable Hydrangeas}

The success of Endless Summer ${ }^{\circledR}$ hydrangea spurred interest in developing and promoting other hydrangeas. Those listed in Table 3 are considered "new" or otherwise notable and some are being promoted with elaborate marketing campaigns. Please remember that most hydrangeas in Table 3 do not normally reflower in the same growing season.

Other new hydrangeas are associated with recent European and Japanese breeding or marketing programs. Hovaria ${ }^{\circledR}$ has introduced a number of Dutch-bred cultivars ('Hobella', 'Hopeline', etc.) that are marketed in the U.S. under the name, Kaleidoscope $^{\circledR}$. The Masters Collection ${ }^{\mathrm{TM}}$ is a series from the Japan Hydrangea Society bred for the garden and cut flower markets with double flowers ('Mikawa Chidori', 'Hanabi' ${ }^{\circledR}$, etc.). Dutch Ladies Collection $^{\mathrm{TM}}$ is a series with women's names $\left(\right.$ Salsa $^{\mathrm{TM}}$, Shakira ${ }^{\mathrm{TM}}$, Samantha ${ }^{\mathrm{TM}}$, etc.) developed in Holland for the cut flower and pot-plant markets; most have large florets with serrated "petals." The Japanese Lady series ('Lady Katsuko', 'Lady Taiko Blue', etc.) was bred by Hiroshi Ebihara of Japan and features picotee florets (with each "petal" edged in white). Many of these cultivars are not widely grown in the U.S. and should be evaluated.

\section{Future Hydrangeas}

Many new breeding programs resulted from the re-emergence of hydrangea as an important garden plant. Growers, collectors and breeders are working to find or develop hydrangeas with additional ornamental characteristics such as double flowers, larger flowers and colorful stems or leaves. In addition, most breeders are searching for greater disease resistance and cold hardiness as well as reflowering capabilities. These efforts indicate we can anticipate many more new hydrangeas in coming years. 


\section{References}

Dirr, Michael A. 2004. Hydrangeas for American gardens. Timber Press, Inc., Portland, OR.

Fox, A.M., D.R. Gordon, J.A. Dusky, L. Tyson, and R.K. Stocker, 2005. IFAS Assessment of the Status of Non-Native Plants in Florida's Natural Areas. http://plants.ifas.ufl.edu/assessment.html. Assessed 14 March 2006.

Griffith, Gene and E. Dean. 2004-2005

Wilkerson Mill Gardens Catalog. http://www.hydrangea.com/. Accessed 10 January 2006.

King, Judith. Hydrangeas! Hydrangeas! http://hydrangeashydrangeas.com/. Accessed 10 January 2006.

Knox, Gary W. 2006. Flowering characteristics of hydrangea selections at the North Florida Research and Education Center in Quincy. NFREC Research Report 2006-04. 4 pp. University of Florida/IFAS, North Florida Research and Education Center, 155 Research Road, Quincy, FL 32351. January 2006.

\section{Additional Notes:}

3. Hydrangea macrophylla has been evaluated using the IFAS Assessment of the Status of Non-Native Plants in Florida's Natural Areas (Fox et al. 2005). This species is not documented in undisturbed natural areas in Florida. Thus, it is not considered a problem species and may be used in Florida. 
Table 1. Hydrangea macrophylla cultivars that are remontant (reflower on new growth).

\begin{tabular}{|c|c|c|c|c|}
\hline \multirow[b]{2}{*}{ Name } & \multirow{2}{*}{$\begin{array}{l}\text { Flower } \\
\text { Type }\end{array}$} & \multicolumn{2}{|c|}{ Flower Color } & \multirow[b]{2}{*}{ Comments } \\
\hline & & Acid Soils & Alkaline Soils & \\
\hline Blushing Bride & Mophead & $\begin{array}{l}\text { White with blue } \\
\text { tint }\end{array}$ & $\begin{array}{l}\text { White with pink } \\
\text { tint }\end{array}$ & $\begin{array}{l}\text { Bred from Endless Summer }{ }^{\circledR} \text { hydrangea; } \\
\text { will be sold as Endless Summer }{ }^{\circledR} \text { Blushing } \\
\text { Bride }\end{array}$ \\
\hline David Ramsey & Mophead & Blue & Pink & $\begin{array}{l}\text { In a planting at UF/IFAS NFREC-Quincy, } \\
\text { flowerheads are colorful an average of } 20 \\
\text { weeks per year }\end{array}$ \\
\hline Decatur Blue & Mophead & Blue & Pink & $\begin{array}{l}\text { In a planting at UF/IFAS NFREC-Quincy, } \\
\text { flowerheads are colorful an average of } 20 \\
\text { weeks per year }\end{array}$ \\
\hline Endless Summer $^{\circledR}$ & Mophead & Blue & Pink & $\begin{array}{l}\text { In a planting at UF/IFAS NFREC-Quincy, } \\
\text { flowerheads are colorful an average of } 33 \\
\text { weeks per year; trademarked name of the } \\
\text { cultivar, 'Bailmer' }\end{array}$ \\
\hline Mini Penny & Mophead & Blue & Pink & Compact plant derived from 'Penny Mac' \\
\hline Oak Hill & Mophead & Blue & Pink & $\begin{array}{l}\text { In a planting at UF/IFAS NFREC-Quincy, } \\
\text { flowerheads are colorful an average of } 21 \\
\text { weeks per year }\end{array}$ \\
\hline Penny Mac & Mophead & Blue & Pink & $\begin{array}{l}\text { From the garden of Penny McHenry, } \\
\text { founder of the American Hydrangea Society }\end{array}$ \\
\hline
\end{tabular}

Table 2. Cultivars that are free-flowering (reflower from old growth). Cultivars are Hydrangea macrophylla unless otherwise noted in "Comments."

\begin{tabular}{||l|l|l|l|l||}
\hline \hline \multirow{2}{*}{ Cultivar } & \multirow{2}{*}{$\begin{array}{c}\text { Flower } \\
\text { Type }\end{array}$} & \multicolumn{1}{c|}{ Acid Soils } & Alkaline Soils & \multicolumn{1}{c||}{ Comments } \\
\cline { 3 - 4 } & Mophead & Blue to purple & Pink to red & Reported to flower heavily until frost \\
\hline Ami Pasquier & Mophead & Blue to purple & Deep pink & $\begin{array}{l}\text { "Petals" are serrated; large flowerheads, } \\
\text { also preferred for drying }\end{array}$ \\
\hline Fuji Waterfall & Mophead & $\begin{array}{l}\text { White (blue } \\
\text { tones as } \\
\text { flowers age) }\end{array}$ & $\begin{array}{l}\text { White (pink } \\
\text { tones as flowers } \\
\text { age) }\end{array}$ & $\begin{array}{l}\text { Double flowers appear to spill from the } \\
\text { large flower head; very beautiful; reported } \\
\text { to repeat-flower until fall; sometimes } \\
\text { considered } H \text {. serrata }\end{array}$ \\
\hline $\begin{array}{l}\text { Generale } \\
\text { Vicomtresse de } \\
\text { Vibraye }\end{array}$ & Mophead & Blue & Pink & $\begin{array}{l}\text { Heavy flowering; flowerheads are very } \\
\text { easy to dry }\end{array}$ \\
\hline $\begin{array}{l}\text { Lilacina } \\
\text { Mme Emile Mouillere }\end{array}$ & Mophead & $\begin{array}{l}\text { White with blue } \\
\text { tint }\end{array}$ & $\begin{array}{l}\text { White with pink } \\
\text { tint }\end{array}$ & $\begin{array}{l}\text { "Petals" are serrated; reported to flower } \\
\text { repeatedly all summer; vigorous plant }\end{array}$ \\
\hline Nikko Blue & Mophead & Blue & Pink & $\begin{array}{l}\text { A standard of the industry, though many } \\
\text { ordinary hydrangeas are wrongly sold } \\
\text { under this name }\end{array}$ \\
\hline Preziosa & Mophead & Purple & Pink to red & $\begin{array}{l}\text { Dark purplish stems; flowers deepen to red } \\
\text { by fall; reportedly very susceptible to } \\
\text { mildew; } \text { H. serrata }\end{array}$ \\
\hline \hline
\end{tabular}


Table 3. Other new or notable cultivars of hydrangea. Most do not normally reflower in the same growing season. Cultivars are Hydrangea macrophylla unless otherwise noted in "Comments."

\begin{tabular}{|c|c|c|c|c|}
\hline \multirow[b]{2}{*}{ Name } & \multirow{2}{*}{$\begin{array}{l}\text { Flower } \\
\text { Type }\end{array}$} & \multicolumn{2}{|c|}{ Flower Color } & \multirow[b]{2}{*}{ Comments } \\
\hline & & Acid Soils & Alkaline Soils & \\
\hline Big Daddy TM & Mophead & Blue & Pink & Extremely large flowerheads \\
\hline Early Sensation & Mophead & Blue & Pink & $\begin{array}{l}\text { Supposedly remontant or free-flowering, } \\
\text { but this plant is untested }\end{array}$ \\
\hline Eclipse & Lacecap & Blue & Pinkish white & White variegated foliage \\
\hline $\begin{array}{l}\text { Forever \& Ever Double } \\
\text { Pink }\end{array}$ & Mophead & Blue to purple & Pink & $\begin{array}{l}\text { Double flowers; supposedly remontant or } \\
\text { free-flowering, but this plant is untested }\end{array}$ \\
\hline Forever \& Ever Pink & Mophead & Blue & Pink & $\begin{array}{l}\text { Supposedly remontant or free-flowering, } \\
\text { but this plant is untested }\end{array}$ \\
\hline Forever \& Ever Red & Mophead & Blue to purple & Pink to dark pink & $\begin{array}{l}\text { Supposedly remontant or free-flowering, } \\
\text { but this plant is untested }\end{array}$ \\
\hline Lady In Red & Lacecap & White & Pinkish white & $\begin{array}{l}\text { Red stems, petioles, and leaf veins; } \\
\text { flowers turn rose-colored as they age; } \\
\text { leaves turn reddish-purple in fall; Plant } \\
\text { Patent \#15175 }\end{array}$ \\
\hline Lemon Wave & Lacecap & Pale blue & White & $\begin{array}{l}\text { Variegated green and white leaves also } \\
\text { have yellow splotches; stems can revert } \\
\text { back to all-green leaves }\end{array}$ \\
\hline Lemon Zest & Mophead & Blue & Pink & $\begin{array}{l}\text { Green foliage aging to chartreuse-yellow; } \\
\text { sometimes sold as Sun Goddess }\end{array}$ \\
\hline Mariesii Variegata & Lacecap & Blue & Pinkish white & Green leaves with white edges \\
\hline $\begin{array}{l}\text { Miyama-yae-Murasaki } \\
\text { ("Purple Tiers") }\end{array}$ & Lacecap & Blue to purple & Pink & $\begin{array}{l}\text { Sometimes called "Purple Tiers"; double } \\
\text { flowers; extremely beautiful; } H \text {. serrata }\end{array}$ \\
\hline
\end{tabular}

